\title{
Seed priming improves the germination and growth rate of melon seedlings under saline stress
}

\author{
Carlos Eduardo da Silva Oliveira ${ }^{1}$ (D) Fábio Steiner ${ }^{1}$ (D) Alan Mario Zuffo $^{2^{*}}$ (D) Tiago Zoz (D) $^{1}$ \\ Charline Zaratin Alves ${ }^{2}$ (D) Viviane Cabrera Baptista de Aguiar $^{2}$ (D)
}

${ }^{1}$ Universidade Estadual de Mato Grosso do Sul (UEMS), Cassilândia, MS, Brasil.

${ }^{2}$ Universidade Federal de Mato Grosso do Sul (UFMS), Chapadão do Sul, MS, Brasil. E-mail: alan_zuffo@hotmail.com. *Corresponding author.

\begin{abstract}
The germination and growth of melon (Cucumis melo L.) plants can be severely affected by excess salts in the soil or irrigation water; however, negative effects of salt stress can be attenuated using appropriate methods of seed priming. Thus, effects of osmopriming as inducer of salt stress tolerance in melon seeds exposed to salinity levels were investigated in this study. Seeds were soaked for 22 h at $25{ }^{\circ} \mathrm{C}$ in the dark in distilled water (hydropriming) or $0.5 \% \mathrm{KNO}_{3}$ solution (osmopriming), and after drying, were distributed in plastic boxes with blotter paper containing different $\mathrm{NaCl}$ solutions prepared with osmotic pressure of $0.0 \mathrm{MPa}$ (control), $-0.3 \mathrm{MPa}$ (mild stress), and -0.6 $\mathrm{MPa}$ (severe stress). Unprimed dry seeds were taken as control. The plastic boxes were kept into a seed germinator, at $25{ }^{\circ} \mathrm{C}$ for 14 days. A completely randomized design in a $3 \times 3$ factorial schemes with four replicates of 25 seeds was used. Results showed that the seed priming with water and $\mathrm{KNO}_{3}$ may be successfully applied on melon seeds to alleviate the adverse effects of saline stress in initial stages of plant growth. However, under severe salt stress conditions, hydropriming should be used because it results in higher germination and initial growth rate of the seedlings when compared to the osmopriming. Use of unprimed seeds should not be adopted in cultivation areas affected by salinity because they result in low germination rate and reduced initial plant growth.
\end{abstract}

Key words: Cucumis melo L., salinity, hydropriming, osmopriming, salt tolerance.

Condicionamento de sementes melhora a germinação e a taxa de crescimento das plântulas de melão sob estresse salino

RESUMO: A germinação e o crescimento de plantas de melão (Cucumis melo L.) podem ser severamente afetadas pelo excesso de sais no solo ou na água de irrigação. No entanto, os efeitos negativos do estresse salino podem ser amenizados com o uso de métodos adequados de condicionamento das sementes. Assim, este estudo objetivou investigar os efeitos do osmocondicionamento como indutor da tolerância ao estresse salino em sementes de melão expostas à níveis de salinidade. As sementes foram imersas por $22 \mathrm{~h}$ à $25{ }^{\circ} \mathrm{C}$ em água destilada (hidrocondicionamento) ou em solução de 0,5\% de $\mathrm{KNO}_{3}$ (osmocondicionamento). Após secagem, as sementes foram distribuídas em caixas plásticas com papel mata-borrão contendo as diferentes soluções de NaCl preparadas com potencial osmótico de 0,0 MPa (controle), -0,3 MPa (estresse suave) e-0,6 MPa (estresse severo). Um tratamento com sementes secas não condicionadas foi utilizado como controle. As caixas plásticas foram mantidas em germinador de sementes, a $25^{\circ} \mathrm{C}$ por 14 dias. O delineamento experimental foi inteiramente casualizado, em esquema fatorial $3 \times 3$, com quatro repetições de 25 sementes. Os resultados mostraram que o condicionamento de sementes com água e $\mathrm{KNO}_{3}$ pode ser aplicado com sucesso em sementes de melão para amenizar os efeitos adversos do estresse salino durante o estágio inicial de crescimento das plantas. No entanto, sob estresse salino severo, o hidrocondicionamento deve ser utilizado por resultar em maior percentagem de germinação e maior taxa de crescimento inicial das plântulas quando comparado ao osmocondicionamento. O uso de sementes de melão sem condicionamento prévio não deve ser adotado em áreas de cultivo afetadas pela salinidade, pois resultam em baixa taxa de germinação e reduzido crescimento inicial das plantas.

Palavras-chave: Cucumis melo L., salinidade, hidrocondicionamento, osmocondicionamento, tolerância à salinidade.

\section{INTRODUCTION}

Brazil is the largest melon (Cucumis melo L.) producer in the world. However, as more than $95 \%$ of its production is concentrated in the semiarid region of northeastern Brazil (IBGE, 2018), the profitability of melon production is often limited due to the excess of salts in the soil or in irrigation water (PEREIRA et al., 2017). Salinity is one of the major abiotic stresses that limit growth and yield of crops in the semiarid areas of Brazil and the world. This is owing to the inappropriate management of irrigation and drainage, low precipitation, high evaporation and irrigation with saline waters (MUNNS \& TESTER, 2008). A soil is saline when the electric conductivity (EC) of the saturated paste extract reaches $4.0 \mathrm{dS} \mathrm{m}^{-1}$ (equivalent to $40 \mathrm{mmol} \mathrm{L}^{-1} \mathrm{NaCl}$ ), generating an osmotic pressure of about $-0.2 \mathrm{MPa}$ (MUNNS \& TESTER, 2008).

Seed germination and seedling growth are two critical stages for the establishment of crops and 
are the most sensitive stages to salinity (FULLER et al., 2012). Salinity may adversely affect seed germination and stand establishment through osmotic stress, ion-specific phytotoxic effects and oxidative stress (ACOSTA-MOTOS et al., 2017). These effects cause adverse changes in the physiological and biochemical of seed germination. High saline levels may inhibit the water uptake of seeds, making germination not possible, while the lower level of salinity induces a state of dormancy (IBRAHIM, 2016). Delayed and reduced seedling emergence causes non-uniform stand establishment, which results in reduced crop yields (LAWLES et al., 2012).

Among the strategies used to mitigate the salinity-induced adverse effects, the priming of seeds within organic salt solutions (osmopriming) or water (hydropriming) are cited as the most appropriate, efficient and economic techniques to enhance the rate and the uniformity of germination under saline conditions (SINGH et al., 2015; MATIAS et al., 2018). Research indicates that nitrate-containing compounds may function more efficiently than other salts as priming agents. Indeed, the priming with potassium nitrate $\left(\mathrm{KNO}_{3}\right)$ solution has been shown to have beneficial effects on germination and growth rate of a wide range of vegetable crops under stressful environments, as in eggplant (NASCIMENTO \& LIMA, 2008), tomato (EBRAHIMI et al., 2014), and pepper (BATISTA et al., 2015). The beneficial effect of the $\mathrm{KNO}_{3}$ application on seed germination is due to the synthesis of substances that release nitric oxide (NO). These substances NO-liberating act in cell membrane permeability, preventing or reversing the damage caused by abiotic stresses (PEREIRA et al., 2010) and; therefore, has potential to improve the germination process under salinity conditions (OLIVEIRA \& STEINER, 2017). According to SANZ et al. (2015), nitric oxide is a molecule that acts as a signaler in higher plants and it is involved in numerous physiological processes that regulate plant growth in response to abiotic stress.

Conversely, MATIAS et al. (2018) recommended the soaking of seeds in water to improve the tolerance of sunflower plants under saline conditions. These authors argued that the hydropriming stands out for its practicality and requires low investments in reagents, compared with the other methods, besides avoiding interference of substances that are harmful to the seeds during soaking. However, the effectiveness of priming of melon seeds with $\mathrm{KNO}_{3}$ or water is still incipient and inconclusive.

The study was carried out to investigate the effects of osmopriming and hydropriming as inducers of salt stress tolerance in melon (Cucumis melo L.) seeds exposed to salinity levels.

\section{MATERIAL AND METHODS}

\section{Plant material and treatments}

Seeds of melon (Cucumis melo L., cv. Gaúcho Casca de Carvalho Comprido) were surface sterilized in $2 \%(\mathrm{v} / \mathrm{v})$ sodium hypochlorite solution for 5 minutes and rinsed three times in distilled water. The sterilized seeds were then primed by soaking with $5 \mathrm{~g} \mathrm{~L}^{-1} \mathrm{KNO}_{3}$ solution (osmopriming) or distilled water (hydropriming) for 22 hours at $25^{\circ} \mathrm{C}$. After priming, seeds were removed and washed with tap water and then put to dry at room temperature $\left(23-28^{\circ} \mathrm{C}\right)$ for 48 hours. A set of unprimed dry seeds was taken as control.

To compare the effect of priming treatments on plant tolerance to saline stress, the seeds were exposed to $0.0,-0.30$ and $-0.60 \mathrm{MPa}$ iso-osmotic solutions with $\mathrm{NaCl}$. The concentration of $\mathrm{NaCl}$ required to obtain the osmotic pressure of -0.3 and $-0.6 \mathrm{MPa}$ was calculated by the van't Hoff equation (HILLEL, 1971): $\Psi_{\mathrm{s}}=-\mathrm{RTCi}$, where $\Psi_{\mathrm{s}}$ is the osmotic pressure ( $\mathrm{MPa})$; $\mathrm{R}$ is the ideal gas constant $\left(0.008314 \mathrm{MPa} \mathrm{mol}^{-1} \mathrm{~K}^{-1}\right)$; $\mathrm{T}$ is the absolute temperature $\left(273.15+{ }^{\circ} \mathrm{C}\right)$; $\mathrm{C}$ is the concentration in molarity of the solute $\left(\mathrm{mol} \mathrm{L}^{-1}\right)$; and $\mathrm{i}$ is the van't Hoff factor, the ratio of amount of particles in solution to the amount of formula units dissolved [i.e., for $\mathrm{NaCl}$ this value is $2.0\left(\mathrm{Na}^{+}\right.$and $\left.\mathrm{Cl}^{-}\right)$].

Treatments were arranged in a completely randomized design in a $3 \times 3$ factorial: three priming treatments [hydropriming (water), osmopriming $\left(0.5 \% \mathrm{KNO}_{3}\right)$ or unprimed seeds] and three salt stress levels [0 MPa (control), $-0.3 \mathrm{MPa}$ (mild stress) and $-0.6 \mathrm{MPa}$ (severe stress)] with four replicates.

\section{Germination and growth conditions}

The germination test was carried out using gerbox plastic boxes $(11.0 \times 11.0 \times 3.5 \mathrm{~cm})$, where four replicates of 25 seeds were evenly distributed on a sheet of blotting paper, properly moistened with the salt solutions of each treatment, at a volume equivalent to three times the weight of the dry paper. Boxes were capped and maintained in a germination chamber under $12 / 12 \mathrm{~h}$ photoperiod (light/darkness), photosynthetic photon flux density (PPFD) of 180 $\mu \mathrm{mol} \mathrm{m} \mathrm{m}^{-2} \mathrm{~s}^{-1}$ and temperature of $25^{\circ} \mathrm{C}$ for 14 days. Thiram fungicide was added to the solutions at a concentration of $0.2 \%(\mathrm{v} / \mathrm{v})$ to limit fungal growth. Seeds were considered germinated when radicle was longer than $5.0 \mathrm{~mm}$. Germinated seeds were recorded every $24 \mathrm{~h}$ for 14 days. 
Measurements of germination and seedling growth

Number of germinated seeds was recorded daily, and as the seed germination process was delayed by salinity conditions, the final germination percentage was evaluated at 14 days. The germination rate index (GRI) was calculated using Maguire's equation (MAGUIRE, 1962): GRI $=\Sigma\left(n_{\mathrm{i}} / t_{\mathrm{i}}\right)$, where $n_{\mathrm{i}}$ is the number of germinated seeds on a given day, and $t_{\mathrm{i}}$ is the time in days from the sowing day (0). The mean germination time (MGT) was calculated using the equation of LABOURIAU (1983): MGT $=\left(\Sigma n_{\mathrm{i}} t_{\mathrm{i}}\right) / \Sigma n_{\mathrm{i}}$, where $n_{\mathrm{i}}$ is the number of germinated seeds on a given day, and $t_{\mathrm{i}}$ is the time in days from the sowing day (0).

Hypocotyl length (HL, in $\mathrm{cm}$ ) and primary root length ( $\mathrm{RL}$, in $\mathrm{cm}$ ) was measured in ten normal seedlings randomly obtained after count of the total germination $\left(14^{\text {th }}\right.$ day) using meter scale. The shoot dry matter (SDM, in $\mathrm{mg}$ ) and root dry matter (RDM, in $\mathrm{mg}$ ) were recorded after oven drying at $65^{\circ} \mathrm{C}$ for $72 \mathrm{~h}$. To determine root: shoot ratio (RSR), root dry matter obtained was divided by the shoot dry matter.

The data of germination percentage, seedling length, and seedling dry matter were used to calculate the seedling vigor and drought tolerance indices. Seedling weight and length vigor indices in each treatment were calculated using following equations, as suggested by ABDUL-BAKI \& ANDERSON (1973): SLVI $=$ [seedling length $(\mathrm{cm})$ $\times$ seed germination $(\%)$ ] and SWVI $=$ [seedling dry weight $(\mathrm{mg}) \times$ seed germination $(\%)]$.

The salt tolerance index was calculated using the equation of BOUSLAMA \& SCHAPAUGH (1984): YSI $=Y_{\mathrm{S}} / Y_{\mathrm{C}}$, where YSI is the yield stability index, $Y_{\mathrm{S}}$ and $Y_{\mathrm{C}}$ is the total dry matter yield (mg per seedling) under saline stress and non-stress conditions (control), respectively.

\section{Statistical analyses}

The normality of data was previously tested by the Kolmogorov-Smirnov test at the 5\% level and then data were submitted to analysis of variance (ANOVA), and means of seed priming and stress levels were compared by Fisher's Least Significant Difference (LSD) test at the 0.05 confidence level. For statistical analysis, the data expressed in percentage were previously transformed into $\arcsin \sqrt{x / 100}$. The analyses were performed using Sisvar ${ }^{\circledR}$ version 5.6 software for Windows (Statistical Analysis Software, UFLA, Lavras, MG, BRA).

\section{RESULTS AND DISCUSSION}

Results of the analysis of variance showed significant effects $(p<0.05)$ for the main effects of seed priming and salinity levels, as well as for interaction, for all measured traits (Table 1). The significant interaction between the main effects of priming and salt stress indicated that the germination, growth, and vigor of melon seedlings from seeds submitted to priming with water (hydropriming) or $\mathrm{KNO}_{3}$ (osmopriming) and unprimed seeds have a distinct response when exposed to different saline stress levels.

\section{Effect of seed priming and salt stress on germination} Seed priming methods do not interfere in the germination process of melon seeds under saltfree control conditions (Figure 1). Under control conditions, the germination percentage ranged from 88 to $94 \%$, whereas the germination rate index and mean germination time ranged from 3.87 to 4.53 seed day $^{-1}$ and 5.8 to 6.6 seed day ${ }^{-1}$, respectively. These results indicated that the germination response of melon seeds has not been improved by hydropriming

Table 1 - Summary of the analysis of variance for the measurements of germination traits, initial growth, dry matter partitioning and vigor indexes of melon seedlings for the effects of seed priming and saline stress.

\begin{tabular}{lcccccccccccc}
\hline $\begin{array}{l}\text { Source of } \\
\text { variation }\end{array}$ & \multicolumn{10}{c}{ Probability $>\mathrm{F}$} \\
\hline & GC & GRI & MGT & HL & RL & SDM & RDM & TDM & RSR & SLVI & SWVI \\
\hline Priming (P) & 0.001 & $<0.000$ & $<0.000$ & $<0.000$ & 0.025 & $<0.000$ & $<0.000$ & $<0.000$ & 0.017 & $<0.000$ & $<0.000$ \\
\hline Salinity (S) & $<0.000$ & $<0.000$ & $<0.000$ & $<0.000$ & $<0.000$ & $<0.000$ & $<0.000$ & $<0.000$ & $<0.000$ & $<0.000$ & $<0.000$ \\
$\mathrm{P} \times \mathrm{S}$ & $<0.000$ & 0.001 & $<0.000$ & 0.003 & $<0.000$ & $<0.000$ & $<0.000$ & $<0.000$ & 0.011 & $<0.000$ & $<0.000$ \\
$\mathrm{CV}(\%)$ & 10.20 & 11.36 & 4.19 & 7.96 & 10.13 & 5.32 & 10.23 & 5.05 & 12.24 & 11.24 & 11.04 \\
\hline
\end{tabular}

GC: germination capacity. GRI: germination rate index. MGT: mean germination time. HL: hypocotyl length. RL: radicle length. SDM: shoot dry matter. RDM: root dry matter. TDM: total dry matter. RSR: root: shoot ratio. SLVI: seedling length vigor index. SWVI: seedling weight vigor index. 


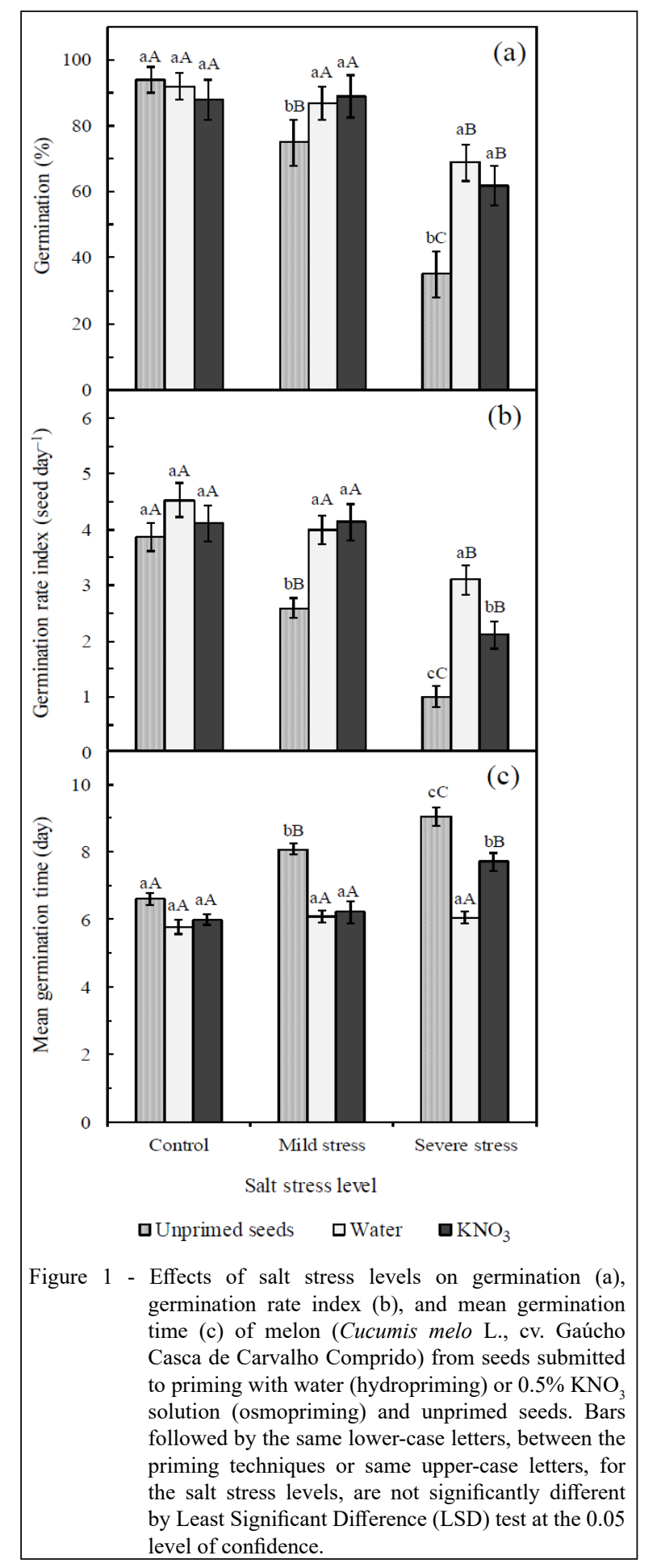

and osmopriming when seeds are exposed to nonstressful environments. Therefore, these priming techniques do not need to be adopted by the vegetable growers when sowing the melon is carried out in salinity-free conditions.
Conversely, when seeds were submitted to mild or severe salt stress the germination rate was significantly greater with hydropriming and osmopriming, and lower for unprimed seeds (Figure 1a). These results showed that priming of melon 
seeds with water or $\mathrm{KNO}_{3}$ was efficient to improve the germination capacity under salinity conditions. Therefore, in field or greenhouse conditions where the soil or substrate is affected by salinity, the growers should use melon seeds primed with water or $\mathrm{KNO}_{3}$ to obtain higher germination percentage and germination rate index, and lower mean germination time (Figure 1).

An improvement in the germination process with seed pre-priming has been commonly reported in several crops. EBRAHIMI et al. (2014) reported that the osmopriming may enhance the seed germination and growth rate of tomato cultivars under salt stress conditions. BATISTA et al. (2015) reported that both hydropriming and osmopriming improved germination and seed germination rate index of pepper seeds compared to unprimed seeds. Matias et al. (2018) indicated that hydropriming improved tolerance of sunflower plants under saline environments. According to KUBALA et al. (2005), the priming can improve germination rate through metabolic activation involving the synthesis of proteins, nucleic acids, and enzymes, and increasing water uptake, respiratory activity, and reserve mobilization.

Germination rate index (GRI) of melon seeds was reduced with the increase of the salt stress level; however, this negative effect can be fully reversed with the hydropriming and osmopriming under mild salt stress (Figure 1b). Under severe salt stress, the GRI ranged from 0.99 to 3.10 seed day ${ }^{-1}$, and was significantly greater when the seeds were primed with water, followed by $\mathrm{KNO}_{3}$ priming, and lower for unprimed seeds (Figure $1 \mathrm{~b}$ ).

The reduction in the germination (Figure 1a) and GRI (Figure 1b) of melon seeds with the increase of the salt stress level was due to increase of external osmotic pressure which affects the water absorption by the seeds, and, also due to the accumulation of $\mathrm{Na}^{+}$and $\mathrm{Cl}^{-}$in the embryo which may lead to an alteration of the metabolic processes of germination and subsequently causing cells death in the embryo (MAHER et al., 2013; ACOSTAMOTOS et al., 2017). Osmotic stress affects the starch synthesis reactions and energy production process (adenosine triphosphate - ATP) through respiration (MARCOS-FILHO, 2015), resulting in reduced of germination (Figure 1a), germination rate index (Figure 1b) and thus in delay of germination time (Figure 1c).

The mean germination time (MGT) was delayed with the rise of salt stress levels, except for hydroprimed seeds (Figure 1c). Under severe salt stress, the MGT was delayed in 2.5 days (from 6.6 to 9.1 days) for the unprimed seeds, in 1.7 days (from 6.0 to 7.7 days) for the seeds primed with $\mathrm{KNO}_{3}$, against 0.3 days (from 5.8 to 6.1 days) for the hydropriming compared to the $\mathrm{NaCl}$ free control. The delay of germination was due to salinity affect the water uptake of the seeds, which is the first step to occur germination process (i.e., imbibition). According to MARCOS-FILHO (2015), it is necessary that seeds reach an adequate level of hydration during the imbibition phase, to occur reactivation of seed metabolic processes and growth of embryonic axis. Seeds subjected to osmotic stress require more time to adjust internal osmotic potential in accordance with the external environment (MUNNS \& TESTER, 2008). Highly negative osmotic pressure may affect the seeds water uptake, making germination not possible (MENESES et al., 2011). Additionally, the osmotic potential of the external medium can affect the enzymatic reactions in the seed; therefore, the delay in germination is due to delay of enzymatic reactions (MARCOS-FILHO, 2015), caused by the break of the imbibition period. The most common responses of plants to the reduction of osmotic pressure are a delay in initial germination and a reduction in the rate and total germination (EBRAHIMI et al., 2014; OLIVEIRA \& STEINER, 2017; MATIAS et al., 2018).

\section{Effect of seed priming and salt stress on initial seedling growth}

The initial growth of melon seedlings was significantly influenced $(p<0.05)$ by the seed priming and salt stress levels (Figure 2). The hypocotyl and primary root length were inhibited by the increase of salt stress level (Figure 2a and 2b). The hypocotyl length of seedlings ranged from 3.16 to $3.74 \mathrm{~cm}$ in the $\mathrm{NaCl}$-free control treatment, whereas under severe salt stress the hypocotyl length ranged from 1.75 to $2.65 \mathrm{~cm}$. Primary root length decreased from $1.34-1.82 \mathrm{~cm}$ in the control treatment to $0.74-1.07$ $\mathrm{cm}$ under severe salt stress. These results indicated that there was a mean reduction in the hypocotyl and primary root length of $36 \%$ and $43 \%$, respectively.

Athighsaltlevels anirreversibleimpairment of the photosynthetic apparatus, associated with a reduction of ribulose-1,5-bisphosphate carboxylase/ oxygenase (Rubisco) activity, occurs when the stress is prolonged, and salt continues to accumulate in the shoots (ACOSTA-MOTOS et al., 2017). In addition, the observed decrease in the hypocotyl and root length could be due to the negative effect of salt on the changes in enzyme activity (that subsequently 


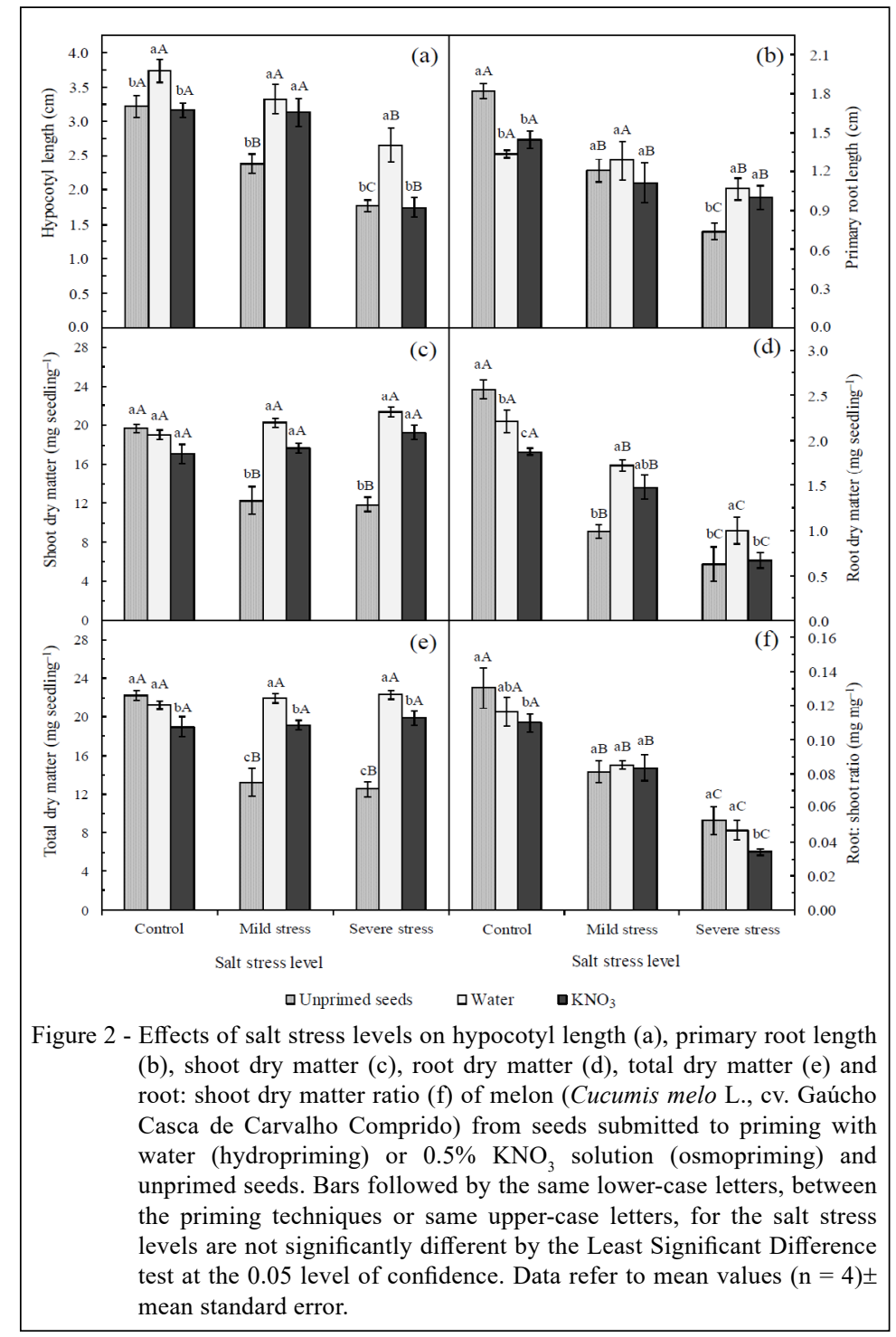

affects protein synthesis), and also the decrease in the carbohydrate levels and growth hormones, both of which can lead to inhibition of the plant elongation (QADOS et al., 2011).

Hydroprimed seeds have greater hypocotyl length when grown under salt-free conditions and under severe stress, whereas under mild salt stress the greater hypocotyl length was obtained for seeds primed with water and $\mathrm{KNO}_{3}$ (Figure 2a). This evidenced that the seed priming, especially with water, improved the shoot growth of the melon seedlings in non-stressful and stressful conditions. Conversely, the higher root length in the control treatment was obtained with the unprimed seeds, and under severe salt stress, the greater root length was obtained when the seeds were primed with water and
$\mathrm{KNO}_{3}$ (Figure 2b). Under mild salt stress, the seed priming treatments did not significantly affect the primary root length.

Research has reported that the effects of seed priming on the seedling elongation are still contradictory. BARBOSA et al. (2016) reported that the priming of watermelon seeds with water and $\mathrm{KNO}_{3}$ produced seedlings with the same shoot length, while hydroprimed seeds resulted in seedlings with greater radicle length compared to the osmopriming. EBRAHIMI et al. (2014) showed that the seed priming with $\mathrm{KNO}_{3}$ may enhance the shoot growth rate of tomato seedlings under high salinity conditions. During the priming period, several processes including activation and synthesis of a number of enzymes, proteins and nucleic acids, repair 
and build up, ATP synthesis, and the cytoplasmic membrane repair in treated seeds will all start to develop (KUBALA et al., 2015), which may increase the relative growth rate of the seedlings. However, OLIVEIRA \& STEINER (2017) showed that the seed priming with water or $\mathrm{KNO}_{3}$ did not affect the shoot and root length of cucumber seedlings under saline stress conditions.

The accumulation of shoot dry matter obtained from unprimed seeds was severely reduced by the mild and severe stress levels; however, this effect was fully reversed with the use of seed priming with water or $\mathrm{KNO}_{3}$ (Figure 2c). These results reported that mild or severe saline stress did not inhibit the shoot dry matter production of seedlings. This suggested that the seed priming improved the shoot growth of the melon plants exposed to salinity. IBRAHIM (2016) reported that seed priming can develop different defense mechanisms in seeds against salinity stress. OLIVEIRA \& STEINER (2017) showed that the priming with water or $\mathrm{KNO}_{3}$ induced osmotic adjustment activity in the cucumber plants exposed to low salinity levels, resulting in higher plant shoot growth; however, high salt levels in the growth medium caused severe inhibition of plant growth.

Conversely, root dry matter production was reduced with salt stress levels for both primed seeds and unprimed seeds; however, primed seeds were less negatively affected by salinity (Figures $2 \mathrm{~d}$ ). Unprimed seeds resulted in higher root dry matter production when grown under salt-free conditions, whereas under mild salt stress the higher root dry matter was obtained for seed priming with water and $\mathrm{KNO}_{3}$ (Figure 2d). Under severe salinity, the higher root dry matter production was obtained for hydroprimed seeds. These results suggested that the seed priming only has capacity of better the dry matter allocation in the roots under salinity conditions. This is because the seed priming can develop different defense mechanisms in seeds against salinity stress (IBRAHIM, 2016). Efficiency of seed priming with water or $\mathrm{KNO}_{3}$ in improving root dry matter accumulation under stressful conditions was also reported in watermelon in eggplant (NASCIMENTO \& LIMA, 2008), tomato (EBRAHIMI et al., 2014), and sunflower (MATIAS et al., 2018).

The total dry matter production obtained from unprimed seeds was severely inhibited by the mild and severe salinity levels; however, this effect was fully reversed with the use of seed priming with water or $\mathrm{KNO}_{3}$ (Figure 2e). This showed that seeds primed in water or $\mathrm{KNO}_{3}$ were not negatively affected by salt stress, or were more able to adjust to the increase of salinity level (Figure 2e). Contrary results were reported by OLIVEIRA \& STEINER (2017), who reported that inhibiting action of salt stress on the initial growth of cucumber seedlings was increased with the rise of salinity levels, and the exposure of seeds to severe salt stress resulted in the decrease of total dry matter in $34 \%$ and $41 \%$ when compared to the $\mathrm{NaCl}$-free control treatment, respectively, for the seed priming with water or $\mathrm{KNO}_{3}$.

The root: shoot ratio is one of several ratios, which give estimates of dry matter partitioning into roots and shoots, and it is a good indicator for abiotic stress effects on root and shoot dry matter (BOUTRAA et al., 2010). The root to shoot ratio of melon seedlings was reduced with the rise of salinity levels both for primed and unprimed seeds (Figure $2 \mathrm{f})$. An increase in the root to shoot ratio was expected to be a common response of plants to salt stress (ACOSTA-MOTOS et al., 2017). The greater root proportion under salt stress can favor the retention of toxic ions in this organ, controlling their translocation to the shoots. This response can constitute a typical mechanism of plant resistance or survival under saline conditions (MUNNS \& TESTER, 2008; ACOSTAMOTOS et al., 2017). Results presented here suggest that the genotype of melon used in this study does not have the capacity to prioritize its allocation of photoassimilates to the roots in detriment to the aerial part and, thus, to improve its tolerances to saline stress. Assimilate partitioning is a complicated process that can be controlled simultaneously by sources and sinks (TAIZ et al., 2017).

The length vigor index (SLVI) of melon seedlings ranged from 473 to 89 , and was drastically reduced with the rise of salt stress levels (Figure 3a). These results evidenced the negative effect of salinity on the elongation of melon seedlings, as reported by the lower length of the hypocotyl (Figure 2a) and primary root (Figure $2 b$ ). The seed priming with water or $\mathrm{KNO}_{3}$ only has a beneficial effect under salt stress conditions. Under mild salinity conditions, the priming with water and $\mathrm{KNO}_{3}$ resulted in higher SLVI when compared to unprimed seeds. Under severe salt stress, the SLVI was significantly greater for hydroprimed seeds, followed by $\mathrm{KNO}_{3}$ priming, and lower for unprimed seeds (Figure 3a). Responses similar to the SLVI were verified for the seedling weight vigor index (SWVI), where seed priming resulted in higher SWVI under salt stress conditions (Figure 3b).

Seedling vigor index has been used as a tolerance index to evaluate the effect of salinity 


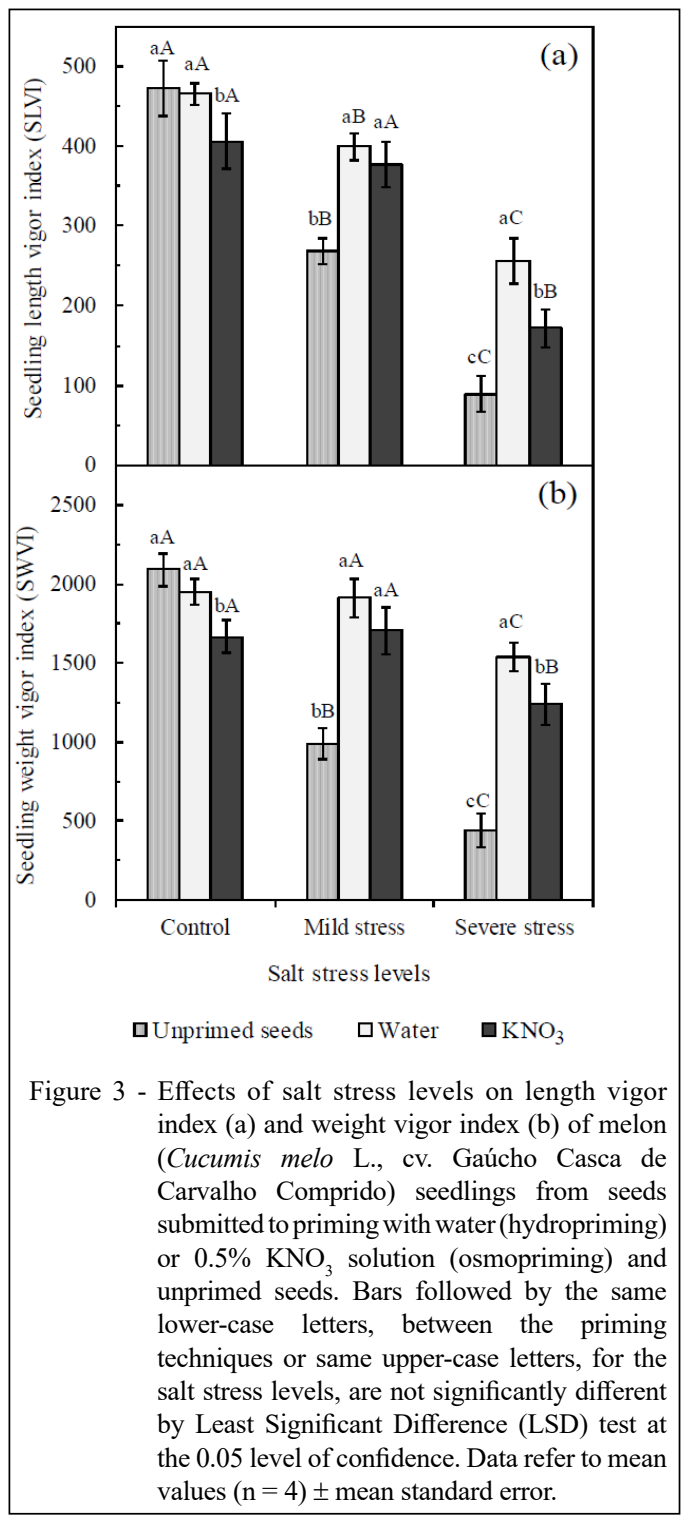

level on seedling growth (ASHKAN \& JALAL, 2013). Seedling vigor is a measure of the extent of damage that accumulates as viability declines, and the damage accumulates in seeds until the seeds are unable to germinate and eventually die (MARCOSFILHO, 2015). Lower seedling vigor index obtained under salinity conditions, especially under severe stress, was due to the salinity inhibit the initial growth of seedlings. Reduction in seedling vigor index under stressful environments is usually reported by other research (ASHKAN \& JALAL, 2013; SINGH et al., 2015; OLIVEIRA \& STEINER, 2017).
The yield stability index of melon seedlings ranged from 0.60 to 1.03 and 0.56 to 1.05 for the seeds exposed to mild and severe saline stress, respectively (Figure 4). The yield stability index was suggested by BOUSLAMA \& SCHAPAUGH (1984) and has been considered a good salt tolerance index. When yield stability index (YSI) in response to saline conditions is greater than 1.0 indicates the high genotype tolerance to salt stress. Therefore, our results clearly showed that seed priming with water or $\mathrm{KNO}_{3}$ was efficient to improve the tolerance of melon plants to salinity. Thus, growers should use 


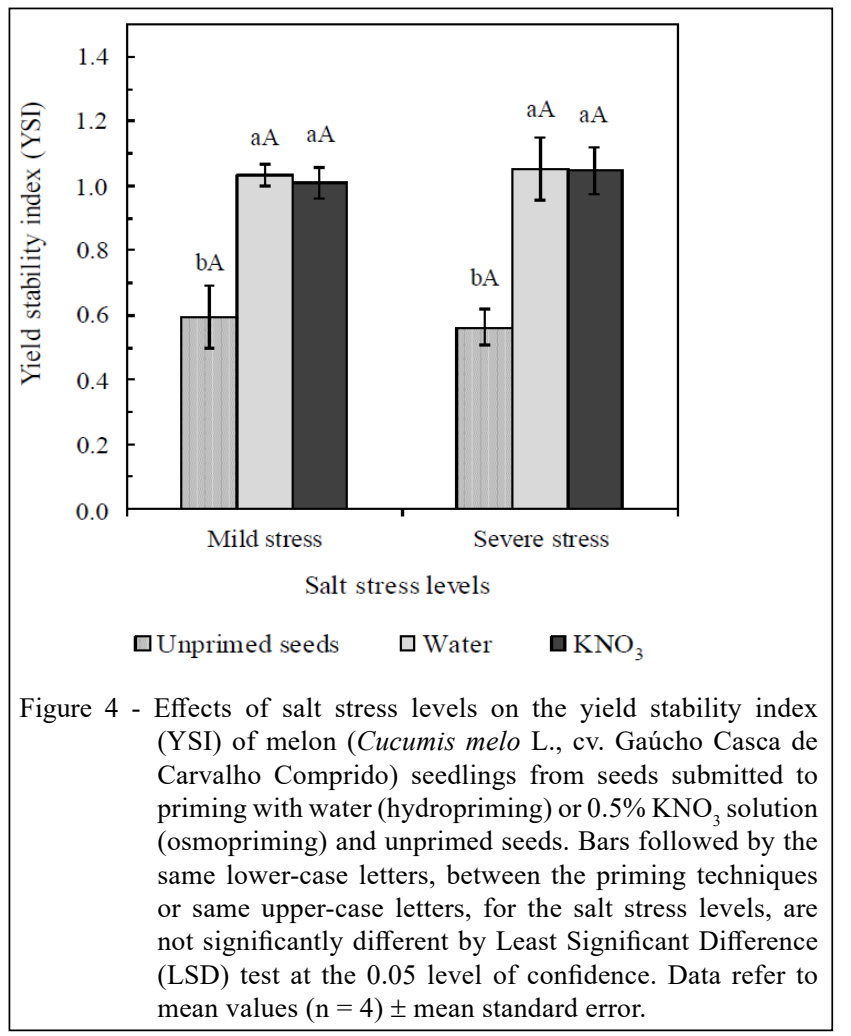

melon seeds primed with water or $\mathrm{KNO}_{3}$ to obtain higher germination percentage and seedling growth rate under saline conditions.

In summary, the results presented here demonstrate that the seed priming with water and $\mathrm{KNO}_{3}$ may be successfully applied on melon seeds to alleviate the negative effects of salinity in the initial stages of plant growth. However, in conditions of severe salt stress, the use of hydropriming should be preferred because it results in higher germination rate, greater dry matter accumulation, higher vigor index and lower mean germination time when compared to the osmopriming. This better performance of melon seeds with direct immersion in water (hydropriming) may be due to the absence of substances harmful to the process of imbibition and seed germination, as can occur with the use of $\mathrm{KNO}_{3}$ salts. According to MARCOS-FILHO \& KIKUTI (2008), the hydropriming induces the reduction of the mean germination time and; consequently, increases the germination rate of the seeds. These authors argued that in stressful environmental conditions, such as in saline soils, the use of hydropriming techniques propitiates the maintenance of the viability and vigor of the seeds. Therefore, the hydropriming stands out for its practicality and requires low investments in reagents, compared with the other methods, besides avoiding interference of substances that are harmful to the seeds during soaking (MATIAS et al., 2018).

\section{CONCLUSION}

Seed priming with water (hydropriming) and $\mathrm{KNO}_{3}$ (osmopriming) may be used to improve seed germination and growth rate of melon seedlings under mild salt stress conditions. Under severe saline conditions, the use of hydropriming should be preferred because it results in more vigorous seedlings.

The use of unprimed seeds should not be adopted in cultivation areas affected by salinity because they result in low germination rate and reduced initial plant growth.

\section{DECLARATION OF CONFLICT OF INTERESTS \\ The authors declared no potential conflicts of interest with respect to the research, authorship, and/or publication of this article.}




\section{AUTHORS' CONTRIBUTIONS}

All authors contributed equally for the conception and writing of the manuscript. All authors critically revised the manuscript and approved of the final version.

\section{REFERENCES}

ABDUL-BAKI, A.A.; ANDERSON, J.D. Vigor determination in soybean seed by multiple criteria. Crop Science, v.13, n.6, p.630633, 1973. Available from: $<$ https://doi.org/10.2135/cropsci1973.0 011183x001300060013x>. Accessed: May, 28, 2018. doi: 10.2135/ cropsci1973.0011183x001300060013x.

ACOSTA-MOTOS, J.R. et. al. Plant responses to salt stress: adaptive mechanisms. Agronomy, v.7, n.1, p.1-18; 2017. Available from: <https://doi.org/10.3390/agronomy7010018>. Accessed: May, 5, 2018. doi: 10.3390/agronomy 7010018 .

ASHKAN, A.; JALAL, M. Effects of salinity stress on seed germination and seedling vigor indices of two halophytic plant species (Agropyron elongatum and A. pectiniforme). International Journal of Agriculture and Crop Sciences, v.5, n.22, p.26692676, 2013. Available from: <http://pakacademicsearch.com/pdffiles/agr/70/2669-2676\%20Number\%2022,\%20VOL.\%205.pdf>. Accessed: Jun. 17, 2018.

BARBOSA, W.F.S. et al. Comparison of seed priming techniques with regards to germination and growth of watermelon seedlings in laboratory condition. African Journal of Biotechnology, v.15, n.46, p.2596-2602, 2016. Available from: $<$ https://doi.org/10.5897/ ajb2016.15279>. Accessed: Jun. 25, 2018. doi: 10.5897/ ajb2016.15279.

BATISTA, T. B. et al. Aspectos fisiológicos e qualidade de mudas da pimenteira em resposta ao vigor e condicionamento das sementes. Bragantia, v.74, n.4, p.367-373, 2015. Available from: $<$ https://doi.org/10.1590/1678-4499.0133>. Accessed: May, 15, 2018. doi: 10.1590/1678-4499.0133.

BOUSLAMA, M.; SCHAPAUGH, W. T. Stress tolerance in soybean. Part 1: evaluation of three screening techniques for heat and drought tolerance. Crop Science, v.24, n.5, p.933-937, 1984. Available from: $<$ https://doi.org/10.2135/cropsci1984.0011183x00 2400050026x>. Accessed: Jun. 15, 2018. doi: 10.2135/cropsci198 $4.0011183 \times 002400050026 \mathrm{x}$

BOUTRAA, T. et al. Effect of water stress on growth and water use efficiency (WUE) of some wheat cultivars (Triticum durum) grown in Saudi Arabia. Journal of Taibah University for Science, v.3, n.1, p.39-48, 2010. Available from: <https://doi.org/10.1016/ s1658-3655(12)60019-3>. Accessed: Jun. 15, 2018. doi: 10.1016/ s1658-3655(12)60019-3.

EBRAHIMI, R. et al. Enhancing stand establishment of tomato cultivars under salt stress condition. South Western Journal of Horticulture, Biology, and Environment, v.5, n.1, p.19-42, 2014. Available from: <http://biozoojournals.ro/swjhbe/v5n1/03 swjhbe_v5n1_Ebrahimi.pdf >.Accessed: May, 16, 2018.

FULLER, M.P. et al. Germination of primed seed under $\mathrm{NaCl}$ stress in wheat. International Scholarly Research Network Botany, v.2012, n.1, p.1-5, 2012. Available from: <https:// doi.org/10.5402/2012/167804>. Accessed: May, 5, 2018. doi: $10.5402 / 2012 / 167804$
HILLEL, D. Soil and water: physical principles and process. New York: Academic Press, 1971. 288p.

IBGE. Instituto Brasileiro de Geografia e Estatística. Levantamento Agrícola. Available from: $<$ https://www.ibge.gov. br/estatisticas>. Accessed: May, 3, 2018.

IBRAHIM, E. A. Seed priming to alleviate salinity stress in germinating seeds. Journal of Plant Physiology, v.192, p.38-46, 2016. Available from: <https://doi.org/10.1016/j. jplph.2015.12.011>. Accessed: May, 15, 2018. doi: 10.1016/j. jplph.2015.12.011.

KUBALA, S. et al. Deciphering priming-induced improvement of rapeseed (Brassica napus L.) germination through an integrated transcriptomic and proteomic approach. Plant Science, v.231, p.94-113, 2015. Available from: <https://doi.org/10.1016/j. plantsci.2014.11.008>. Accessed: May, 15, 2018. doi: 10.1016/j. plantsci.2014.11.008

LABOURIAU, L.G. A germinação de sementes. Washington: Organização dos Estados Americanos, 1983. 174p.

LAWLES, K. et al. Effect of delayed emergence on corn grain yields. Journal of Plant Nutrition, v.35, n.3, p.480-496, 2012. Available from: < https://doi.org/10.1080/01904167.2012.639926 >. Accessed: May, 18, 2018. doi: 10.1080/01904167.2012.639926.

MAGUIRE, J.D. Speeds of germination-aid selection and evaluation for seedling emergence and vigor. Crop Science, v.2, n.2, p.176-177, 1962. Available from: <https://doi.org/10.2135/cr opsci1962.0011183x000200020033x>. Accessed: May, 27, 2018. doi: $10.2135 /$ cropsci1962.0011183x000200020033x

MAHER, S. et al. Effect of $\mathrm{NaCl}$ priming on seed germination of Tunisian fenugreek (Trigonellafoenum graecum L.) under salinity conditions. Journal of Stress Physiology and Biochemistry, v.9, n.2, p.86-96, 2013. Available from: < https://cyberleninka. $\mathrm{ru} /$ article/v/effect-of-nacl-priming-on-seed-germination-oftunisian-fenugreek-trigonella-foenum-graecum-1-under-salinityconditions $>$. Accessed: May, 10, 2018.

MARCOS-FILHO, J. Fisiologia de sementes de plantas cultivadas. Londrina: ABRATES, 2015. 660p.

MARCOS-FILHO J; KIKUTI ALP. Condicionamento fisiológico de sementes de couve-flor e desempenho das plantas em campo. Horticultura Brasileira, v.26, p.165-169, 2008. Available from: $\quad<$ http://dx.doi.org/10.1590/S0102-05362008000200007>. Accessed: Jan. 27, 2019. doi: 10.1590/S0102-05362008000200007.

MATIAS, J. R. et al. Hydropriming as inducer of salinity tolerance in sunflower seeds. Revista Brasileira de Engenharia Agrícola e Ambiental, v.22, n.4, p.255-260, 2018. Available from: <http:/ dx.doi.org/10.1590/1807-1929/agriambi.v22n4p255-260>. Accessed: May, 12, 2018. doi: 10.1590/1807-1929/agriambi. v22n4p255-260.

MENESES, C.H.S.G. et al. Germination of cotton cultivar seeds under water stress induced by polyethylene glycol-6000. Scientia Agricola, v.68, n.2, p.131-138, 2011. Available from: $<$ https://doi. org/10.1590/s0103-90162011000200001>. Accessed: May, 12, 2018. doi: 10.1590/s0103-90162011000200001.

MUNNS, R.; TESTER, M. Mechanisms of salinity tolerance. Annual Review of Plant Biology, v.59, p.651681, 2008. Available from: <https://doi.org/10.1146/annurev. 
arplant.59.032607.092911>. Accessed: May, 15, 2018. doi: 10.1146/annurev.arplant.59.032607.092911.

NASCIMENTO, W.M.; LIMA, L.B. Condicionamento osmótico de sementes de berinjela visando a germinação sob temperaturas baixas. Revista Brasileira de Sementes, v.30, n.2, p.224227, 2008. Available from: <https://doi.org/10.1590/s010131222008000200029>. Accessed: May, 12, 2018. doi: 10.1590/ s0101-31222008000200029.

OLIVEIRA, C.E.S.; STEINER, F. Potassium nitrate priming to mitigate the salt stress on cucumber seedlings. Scientia Agraria Paranaensis, v.16, n.4, p.454-462, 2017. Available from: <http:// dx.doi.org/10.18188/1983-1471/sap.v16n4p454-462>. Accessed: Jun. 10, 2018. doi: 10.18188/1983-1471/sap.v16n4p454-462.

PEREIRA, B.L.C. et al. Influência do óxido nítrico na germinação de sementes de Plathymenia reticulata Benth com baixo vigor. Scientia Forestalis, v.38, n.88, p.629-636, 2010. Available from: <http://www.ipef.br/publicacoes/scientia/nr88/cap09.pdf>. Accessed: Sep 25, 2018.

PEREIRA, F.A.L. et al. Tolerance of melon cultivars to irrigation water salinity. Revista Brasileira de Engenharia Agrícola e
Ambiental, v.21, n.12, p.846-851, 2017. Available from: <http:// dx.doi.org/10.1590/1807-1929/agriambi.v21n12p846-851>. Accessed: May, 5, 2018. doi.org/10.1590/1807-1929/agriambi. v21n12p846-851

QADOS, A.M.S.A. Effect of salt stress on plant growth and metabolism of bean plant Vicia faba (L.). Journal of the Saudi Society of Agricultural Sciences. v.10, n.1, p.7-15, 2011 Available from: <https://doi.org/10.1016/j.jssas.2010.06.002>. Accessed: Jun. 11, 2018. doi: 10.1016/j.jssas.2010.06.002.

SANZ, L. et al. Nitric oxide (NO) and phytohormones crosstalk during early plant development. Journal of Experimental Botany, v.66, n.10, p.2857-2868, 2015. Available from: <https:// doi.org/10.1093/jxb/erv213>. Accessed: Sep. 25, 2018. doi: $10.1093 /$ jxb/erv213.

SINGH, S. et al. Assessment of multiple tolerance indices for salinity stress in bread wheat (Triticum aestivum L.). Journal of Agricultural Science, v.7, n.3, p.49-57, 2015. Available from: $<$ https://doi.org/10.5539/jas.v7n3p49>. Accessed: May 12, 2018. doi: $10.5539 /$ jas.v7n3p49.

TAIZ, L. et al. Fisiologia e Desenvolvimento vegetal. Porto Alegre: Artmed, 2017. 854p. 